\title{
Website Quality and The Role of Customer Satisfaction Toward Repurchase Intention: A Study of Indonesian E-Commerce
}

\author{
Nugroho Hardiyanto ${ }^{1 *}$, Anhari Firdaus ${ }^{2}$ \\ ${ }^{1}$ Department of Business Administration, Politeknik Negeri Bandung, Bandung, Indonesia \\ ${ }^{2}$ Department of Business Administration, Politeknik Negeri Bandung, Bandung, Indonesia \\ Correspondence: E-mail: nugroho.hardivanto@polban.ac.id
}

\begin{abstract}
:
During COVID-19 pandemic, e-commerce sector in Indonesia showed a significant rise in visitors based on the survey of Katadata. The number of visits to e-commerce websites is very high in the third quarter of 2020. Additionally, the e-commerce sector is one of the highest contributors to Indonesia's gross domestic product (GDP). Thus, increasing consumer satisfaction and repurchase intention is essential for companies, especially in fashion products. This study aims to measure website quality on repurchase intention through the role of consumer satisfaction in the context of e-commerce in Indonesia. Furthermore, website quality has dimensions such as information quality, system quality, and e-service quality. This study uses a descriptive quantitative approach that focuses on e-commerce in Indonesia. The data is collected through an online questionnaire which is distributed to 333 consumers who used e-commerce to buy fashion products and used for further analysis. To analyze each variable, partial least squares structural equation modeling (PLSSEM) is used to test the hypotheses. This study found that all dimensions of website quality and customer satisfaction are determining factors in repurchase intention. Then, customer satisfaction is an essential factor to encourage repurchase intention in website quality. This study extends our understanding of website quality theory in the e-commerce context.
\end{abstract}

Keywords:

Website quality, consumer satisfaction, repurchase intention, e-commerce, fashion

\section{ARTICLE INFO}

\section{Article History:}

Received 29 Aug 2021

Revised 07 Sept 2021

Accepted 08 Sept 2021

Available online 27 Sept 2021 


\section{INTRODUCTION}

In recent years, e-commerce popularity develops rapidly (Ajay Kaushik \& Potti Srinivasa, 2017). Additionally, e-commerce has become part of the daily shopping routine of consumers (Tam, Loureiro, \& Oliveira, 2019). Consumers think that e-commerce websites are easy to use, have simple login and purchase processes, and provide a sense of security in payments (Singh, Malik, \& Sarkar, 2016). According to KataData (2020b), visitors to e-commerce websites in Indonesia for the third quarter of 2020 are as follow: Shopee (96.5 million visitors), Tokopedia (85 million visitors), and Bukalapak (31.4 million visitors). During the COVID-19 pandemic, ecommerce experienced an increase in activity in serving consumer purchases in Indonesia by 69\% (KataData, 2020b). Afterward, Statista (2019) stated that the total revenue from the Indonesian e-commerce market throughout 2019 reached US\$ 18.8 billion, grew by $56 \%$ from the previous period of US\$ 12 billion. The fashion sector is the most popular sector among ecommerce users, dominating $30 \%$ of total transactions (Katadata, 2020a). This indicates that e-commerce is one of the important platforms in serving consumers digitally, especially in the fashion sectors by improving the quality of the website.

Website quality in e-commerce is one of the keys to success and can provide sales benefits (Sharma \& Lijuan, 2015). Researchers reveal that websites on e-commerce affect consumers online. Thus, website quality is essential for consumers on e-commerce platforms (Sun, Yang, Wang, \& Zhang, 2015). Website quality is an opportunity for companies to digitally formulate strategies, such as developing interactions and establishing closer relationships with consumers (Galati, Crescimanno, Tinervia, \& Siggia, 2016). In particular, Lin (2007) stated the website quality with an attractive information system (IS) design could provide knowledge and satisfaction for consumers.

On the other hand, the website quality of e-commerce positively influences consumer satisfaction and the value of buying from consumers. Therefore, website quality can predict the quality perceived by customers so that it influences customer satisfaction. In previous research, Lin (2007) found that website quality significantly affects consumer satisfaction. Customer satisfaction on website quality significantly affects repurchase intentions (Phuong \& Dai Trang, 2018). However, past studies show the research of website quality on available products in e-commerce which have less focus on specific products. For example, studies conducted by Lin (2007) and Tam et al. (2019) concentrate on general development. This paucity needs to be addressed with studies that involve fashion products.

Taking the previous researches into account, this study measures the website quality of e-commerce in Indonesia to increase consumer repurchase intentions through the role of consumer satisfaction. Thus, the understanding of website quality can be known theoretically and practically, especially in the context of e-commerce in Indonesia. Based on previous phenomena and data, it can provide an overview and direction for companies in developing website quality strategies and increasing consumer satisfaction on fashion products.

\section{LITERATURE REVIEW}

\subsection{Repurchase Intention}

The repurchase intention is defined as an individual's judgment about purchasing the service again, the decision to engage in future activities with the company or service provider 
(Sharma \& Lijuan, 2015). Nowadays, Suhaily and Soelasih (2017) explained that consumers are interested in making repeated purchases in online shopping, and consumers can provide recommendations about the websites or sites they use to others. As a result, consumers repurchase intention to buy products in the future and reduce information before buying or even using (Tresna, Suryanto, \& Haidysirly, 2019). In the previous study, Wilson and Christella (2019) found that website quality and customer satisfaction affect consumers positively and significantly towards repurchase intention.

\subsection{Website quality}

In the e-commerce industry, website quality has become an essential role for the company's digital progress Wilson and Christella (2019). The website is the key to the company's success, acting as a channel of communication and service between the company and the company customer (Qalati et al., 2021). Website quality is a necessary concept because it is the perception of customers about the quality of a website and directly encourages buying interest from consumers (Kuo, Wu, \& Deng, 2009). Furthermore, Ford, Huerta, Diana, Kazley, and Menachemi (2013) explain that the website quality in e-commerce is based on the standards used for security at every consumer visit. So, overall website quality must display professionalism to attract customers to buy or even retain customers who visit the website (Tsao, Hsieh, \& Lin, 2016). In previous studies, website quality has dimensions that include system quality, information quality, and e-service quality in e-commerce (DeLone \& McLean, 2004; Tsao et al., 2016).

\subsubsection{System quality}

System quality is the overall performance on a website that can be measured by the level of friendliness and security felt by consumers during online shopping (Lin, 2007). Then, system quality is the performance of a website system in conveying information and is easily understood by consumers, and refers to the efficient use of technology (Ajay Kaushik \& Potti Srinivasa, 2017). Thus, system quality is essential for an e-commerce website (Tsao et al., 2016). Furthermore, if consumers quickly and easily find what they are looking for on a website system, it can create customer satisfaction (Filieri, McLeay, \& Tsui, 2017). G. Kim, Shin, and Kwon (2012) stated that system quality could also provide satisfaction to consumers through technical and functional support such as software in e-commerce. In a previous study, Tam et al. (2019) found that system quality significantly affects consumer satisfaction. Then, system quality significantly affects repurchase intention (A. Tandon, Aakash, \& Aggarwal, 2020). Thus, the hypothesis related to system quality is as follows:

$\mathrm{H}_{1}$ : System quality positively influences customer satisfaction.

$\mathrm{H}_{2}$ : System quality positively influences repurchase intention.

\subsubsection{Information quality}

Information quality can be measured by the value felt by consumers when visiting the website (Lin, 2007). Then, information quality on e-commerce websites can create value for customers and is seen from product quality, system design, quality of software products offered to consumers (Sharma \& Lijuan, 2015). Information quality regarding reviews, product descriptions, payment, and delivery details can provide perceptions of satisfaction for consumers in e-commerce platforms (Zhang, Xu, Zhao, \& Yu, 2018). Furthermore, (Tam et al., 2019) explains that information quality in e-commerce can satisfy users or consumers. In a previous study, Tam et al. (2019) found that information quality significantly affects consumer 
satisfaction. Another study explained that information quality had a significant influence on repurchase intention (Prastiwi \& Iswari, 2019). Thus, the hypotheses related to information quality are as follows:

$\mathrm{H}_{3}$ : Information quality positively influences customer satisfaction.

$\mathrm{H}_{4}$ : Information quality positively influences repurchase intention.

\subsection{3. e-Service Quality}

In recent years, e-service quality has become the key to the success of e-commerce websites (Tsao et al., 2016). Then, e-service quality can be defined as an overall consumer evaluation of a service offered in the marketplace (Zehir \& Narcıkara, 2016). Furthermore, Parasuraman, Zeithaml, and Malhotra (2005) explain that e-service quality broadly includes all consumer interactions with a website, such as an extent to which the site provides facilities for shopping, purchasing, and shipping an item effectively. E-service quality on e-commerce websites can identify the main factors of consumer perceptions, such as convenience and security (Chinomona, Masinge, \& Sandada, 2014). Previous studies found that e-service quality has a significant effect on customer satisfaction. Oni, Adewoye, and Eweoya (2016) found that e-service quality significantly influences repurchase intention. Thus, the hypotheses related to e-service quality are as follows:

$\mathrm{H}_{5}$ : e-Service quality positively influences customer satisfaction.

$\mathrm{H}_{6}$ : e-Service quality positively influences repurchase intention.

\subsection{Customer satisfaction}

Consumer satisfaction is one of the fundamental concepts in some marketing literature. Customer satisfaction can measure the services provided by a website, and it also strengthens the relationship between customer perceptions and company services (Jeon \& Jeong, 2017). In an online context, consumer satisfaction from an e-commerce site can represent their satisfaction concerning their previous product purchase experience through e-commerce sites specific websites (Camilleri, 2021). Furthermore, online customer satisfaction can be measured when customers make online purchases on the website, make appropriate choices when choosing products on the website, and feel satisfied when making purchases on the website (Rohwiyati \& Praptiestrini, 2019). On the other hand, customer satisfaction is essential in understanding consumer needs and desires, and it also impacts repurchase intention (Phuong \& Dai Trang, 2018). In a previous study, U. Tandon, Kiran, and Sah (2017) found that customer satisfaction can significantly affect repurchase intention. Thus, the hypotheses related to customer satisfaction are as follows;

$\mathrm{H}_{7}$ : Customer satisfaction positively influences repurchase intention.

\subsection{The Proposed Research Model}

The proposed research model is based on previous studies; this section discusses the research model proposed for this study. The model in this study is proposed to assess website quality influences toward repurchase intention (see figure 1). This model is adopted from several past studies (Hsu, Chang, \& Chen, 2012; Lin, 2007; Tam et al., 2019) 


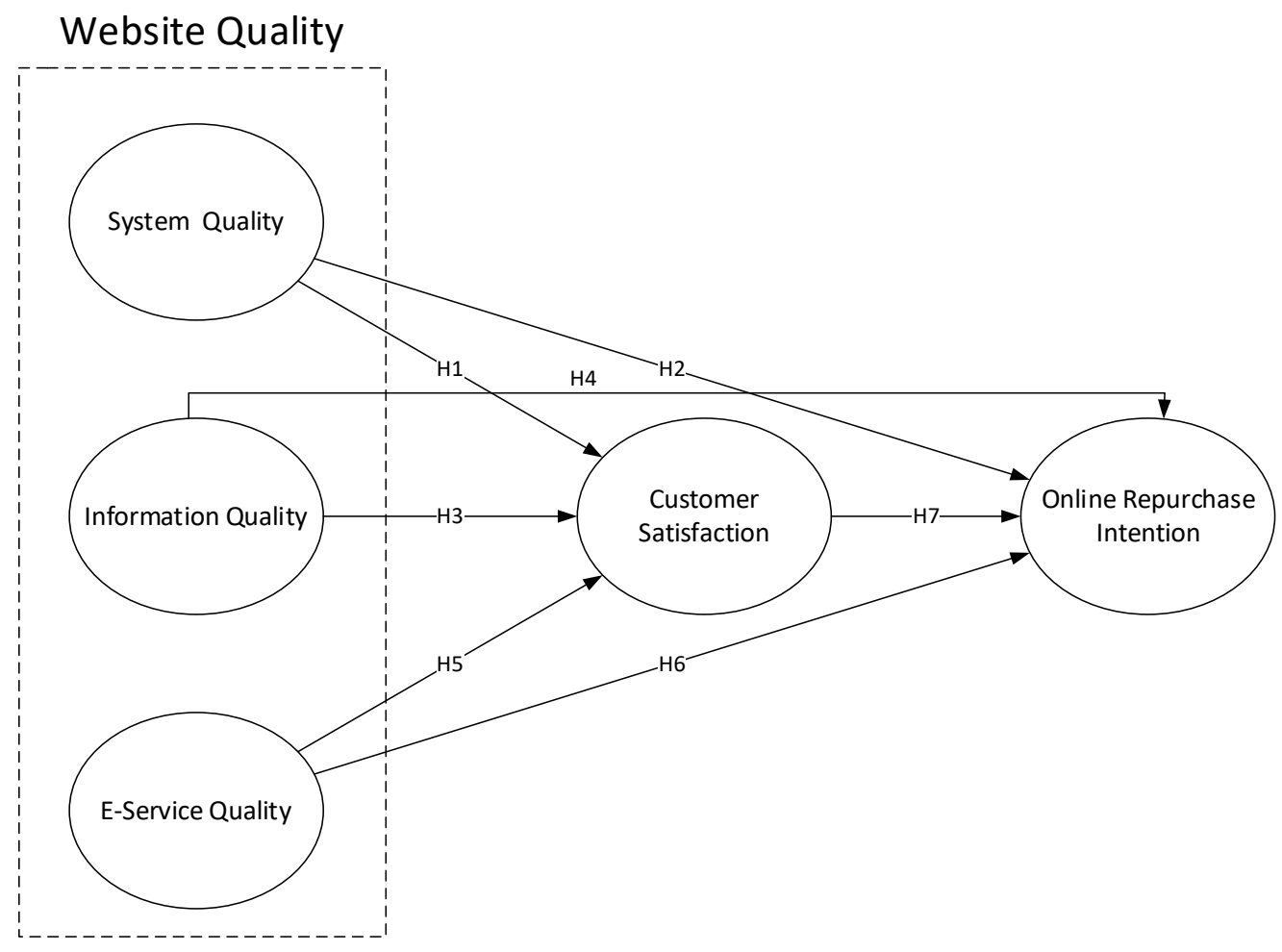

Figure 1 The Proposed Research Model

\section{METHODS}

\subsection{Variable measurement}

Variable measurements in the context of e-commerce were compiled and designed based on previous research. The primary data is collected through a questionnaire. The instruments in the questionnaire were adapted from previous research on the context of ecommerce for fashion products. First, system quality has four questions adapted from Tam et al. (2019) and Lin (2007). Second, information quality has four questions adapted from Tam et al. (2019). E-service quality has three questions adopted from Tam et al. (2019). Then, customer satisfaction has three questions adopted from Hsu et al. (2012). Last, repurchase intention was adopted from (Shin, Chung, Oh, \& Lee, 2013).

The method used to measure the variables is a Likert scale $(1=$ Strongly disagree $-5=$ Strongly agree) (Suhartanto, 2014). The pretest is used to minimize ambiguity or meaning in the questionnaire. The pilot test has been tested on 50 consumers that use e-commerce for buying the fashion products. As a result, from the pilot test, several dictions are different and changed but have the same meaning. So, this questionnaire is suitable for data collection.

\subsection{Data collection and sample}

In analyzed a sampling design, several things need to be understood, including (1) a population or a group of people or goods that have similar characteristics; (2) The sample which is a small part of the population; and (3) Sampling, namely the process of determining the sample based on the number of population (Suhartanto, 2014). The sample in this study are consumers who have bought fashion products on e-commerce. The data collected were from 333 samples. 


\subsection{Data analysis}

This study used variance-based partial least squares (PLS-SEM) and applied SmartPLS 3.2.8 to examine the measurement and structural model. First, the measurement model consists of the factor loading, Cronbach Alpha (CA), Composite Reliability (CR), and Average Variance Extracted (AVE). Discriminant validity of this study applying the Fornell-Larcker Criterion. Meanwhile, the structural model test was carried out on the Goodness of fit (GoF), coefficient determination $\left(R^{2}\right)$, path coefficient, Cross-Validated Redundancy $\left(Q^{2}\right)$, effect size $\left(f^{2}\right)$. Lastly, this study also uses IBM SPSS Statistics 23 to evaluate assess respondent demographic and descriptive statistics.

\section{RESULTS AND DISCUSSION}

\subsection{Respondent's profile}

This study has the respondents' demographic information such as gender, age, occupation, and income (per month). On the other hand, this study uses a situational analysis that offers respondents options for shopping frequency in the last five months. Meanwhile, the percentages and their frequencies will be described. After the data is collected, it is processed using statistical tools (SPSS). The data used in this study were 333 respondents with various characteristics of respondents, which are shown in Table 1. Based on Table 1, it is shown that $52.3 \%$ or 174 respondents are female. While the remaining $47.7 \%$ or 159 respondents are male. As for the age demographic, it is grouped into four groups, which are 18-24, 25-30, 31-35, and > 35 years. In this study, the respondents that are aged 18-24 are 191 people that is $57.4 \%$ of the total respondents. $25.8 \%$ or 86 respondents are aged $25-30$, while $12.6 \%$ or 42 respondents are aged $30-35$. The remaining $4.2 \%$ or 14 respondents are belong to those over 35 years old.

Meanwhile, the occupation of the respondents in this study is classified into five groups: students, employees, entrepreneurs, lecturers or teachers, and housewives. From the data, it is shown that most respondents are students (183 or $55 \%$ in total). While $19.5 \%$ or 65 respondents are employees. $12.3 \%$ or 41 respondents are entrepreneurs. $7.8 \%$ or 26 are lecturers/teachers. Conversely, the smallest group in this study which has $5.4 \%$ of the total respondents which are 18 respondents, are housewives. Moreover, Table 1. shows that 198 of the 333 respondents (59.5\%) earn less than IDR 3,000,000 per month. 76 respondents (22.8\%) have an income of IDR 3,000,000 to IDR 5,000,000 per month. Then, 47 respondents (14.1\%) have an income of IDR 6,000,000 to IDR 10,000,000. And 12 respondents (3.6\%) have a monthly income above IDR $10,000,000$. Also, Table 1 shows that the respondents that used Shopee as it is the most often used e-commerce are 198 people $(59.5 \%)$ with the frequency of purchases on e-commerce $1-2$ in the last five months is 180 (54,1\%)

Table 1 Respondent's profile

\begin{tabular}{clll}
\hline Variable & \multicolumn{1}{c}{ Description } & Frequency & $\%$ \\
\hline \multirow{2}{*}{ Gender } & Male & 159 & 47,7 \\
& Female & 174 & 52,3 \\
\multirow{2}{*}{ Age } & $18-24$ & 191 & 57,4 \\
& $25-30$ & 86 & 25,8
\end{tabular}




\begin{tabular}{clll} 
& $31-35$ & 42 & 12,6 \\
& $>35$ & 14 & 4,2 \\
& Student & 183 & 55,0 \\
& Employee & 65 & 19,5 \\
\multirow{2}{*}{ Occupation } & Entrepreneur & 41 & 12,3 \\
& Lecture/Teacher & 26 & 7,8 \\
& House wife & 18 & 5,4 \\
& $<3$ & 198 & 59,5 \\
& $3-5$ & 76 & 22,8 \\
Income (Million) & 6 - 10 & 47 & 14,1 \\
& $>10$ & 12 & 3,6 \\
& Shopee & 198 & 59,5 \\
& Bukalapak & 52 & 15,6 \\
& Tokopedia & 63 & 18,9 \\
E-commerce website used & Blibli.com & 14 & 4,2 \\
& Others & 6 & 1,8 \\
\hline \multirow{2}{*}{ Shopping frequency in the last 5 } & $1-2$ & 180 & 54,1 \\
months & $3-4$ & 102 & 30,6 \\
& $>5$ & 51 & 15,3 \\
\hline
\end{tabular}

\subsection{Measurement Model}

The asses measurement model involves several instruments, Hair, Ringle, and Sarstedt (2011) explain the tools include Consistency Reliability, Indicator Reliability, Convergent validity, and Discriminant Validity. Therefore, the results of the measurement model are shown in Table 2 and Table 3.

Meanwhile, the results of the outer loading are shown in table 3 . The outer loading is declared valid if the value is above the cut-off value of 0.7 , but if it is less than 0.7 , it is still valid above 0.4 (Hair et al., 2011). Thus, the outer loading value in this study is declared valid based on the literature. Furthermore, Consistency Reliability suggests a Cut-off value of more than 0.7. Meanwhile, the test for Average Variance Extracted (AVE) test shows that all convergent indicators are valid because fulfilled the cut-off value of 0.5 (Hair, Sarstedt, Ringle, \& Mena, 2012).

Furthermore, (Hair Jr, Sarstedt, Ringle, \& Gudergan, 2017) result is that all variables in this study are valid. The reason is that all latent variables account for more variance in its associated indicator variables than it shares with another construct in the same model. According to the literature on its construct, the Fornell-Larcker criterion has a value in this study (see Table 3). Thus, this study has fulfilled all the criteria related to assessing the measurement model according to the previous literature.

Table 2 Loading, Cronbach Alpha (CA), Composite Reliability (CR), and AVE

\begin{tabular}{|c|c|c|c|c|}
\hline Construct/Item & Loading** & $C A$ & $C R$ & AVE \\
\hline System Quality & & 0,711 & 0,821 & 0,536 \\
\hline Easy to use & 0,828 & & & \\
\hline
\end{tabular}


E-commerce websites make it easy to find information $\quad 0,706$

$\begin{array}{ll}\text { An E-commerce website works well } & 0,647\end{array}$

The appearance of the website is very attractive $\quad 0,736$

\section{Information Quality}

$0,710 \quad 0,820 \quad 0,533$

Information about fashion products

0,754

Fashion product information is easy to understand $\quad 0,759$

Interesting information $\quad 0,662$

The information is very complete $\quad 0,742$

\section{e-Service Quality}

$0,723 \quad 0,843 \quad 0,643$

Easy to find fashion products on e-commerce websites $\quad 0,762$

E-commerce websites deliver what they promise

0,804

Convenient when buying fashion products from e-

commerce websites.

0,838

\section{Customer satisfaction}

Satisfied using e-commerce websites

Recommend e-commerce websites to others

Satisfied when interacting on e-commerce websites

\section{Repurchase Intention}

Using e-commerce website for next product purchase

Using e-commerce websites in the future

Make a product purchase on the same website

Note: ${ }^{* *}$ All of them is significant on $p<0.01$

0,799

0,817

0,820

$0,863 \quad 0,916 \quad 0,785$
$0,743 \quad 0,853 \quad 0,659$

0,900

0,898

0,860

Table 3 Fornell-Larcker Criterion

\begin{tabular}{llllll}
\hline & $(1)$ & $(2)$ & $(3)$ & $(4)$ & $(5)$ \\
\hline (1) Customer satisfaction & 0,812 & & & & \\
(2) e-Service quality & 0,548 & 0,802 & & & \\
(3) Information quality & 0,602 & 0,642 & 0,730 & & \\
(4) Repurchase intention & 0,663 & 0,610 & 0,646 & 0,886 & \\
(5) System quality & 0,647 & 0,654 & 0,708 & 0,671 & 0,732 \\
\hline
\end{tabular}

\subsection{Structural Model}

After the Measurement model has been assessed, the next step to validate the model used in this study is to calculate the Goodness of fit (Gof) (Tenenhaus, Vinzi, Chatelin, \& Lauro, 2005). . Afterward, (Hair Jr et al., 2017) explained that GoF is divided into three categories 0.1 (small), 0.25 (moderate), the last 0.36 (large). Table 4 shows the GoF value in this study (0.574) was included in the large category so that the proposed model was of good quality. Calculations on GoF also need to be done in testing the inner model to determine the suitability of the research model being built. By conducting a model fit test, it can be decided whether the approximate model is fit or not (Malhotra, Birks, \& Nunan, 2017). Therefore, Malhotra et al. (2017) recommend that the approximate fit model criteria should be implemented for Standardized Root Mean square Residual (SRMR) with a cut-off value of 0.08 and Normed Fit Index (NFI) with a value close to 1 and above 0.9. As a result, this study has 
an SRMR value of 0.074 and an NFI value of 0.762 . The result from this study shows that if one of the criteria is not fulfilled, the other criteria have been fulfilled. Thus, this research still meets the requirements regarding the model fit so that the analysis can be carried out further.

Table 4 Goodness of fit (Gof)

\begin{tabular}{lccc}
\hline \multicolumn{1}{c}{ Variable } & AVE & $R^{2}$ & $Q^{2}$ \\
\hline System quality & 0,536 & & \\
Information quality & 0,533 & & \\
e-Service quality & 0,643 & & \\
Customer satisfaction & 0,659 & 0,466 & 0,289 \\
Repurchase intention & 0,785 & 0,577 & 0,426 \\
Average Score & 0,631 & 0,522 & \\
AVE X $R^{2}$ & & 0.329 & \\
GoF $=\sqrt{ }($ AVE x R2) & & 0.574 & \\
\hline
\end{tabular}

Then, the model quality assessment is from its capability to figure out endogenous constructs through $R^{2}, Q^{2}$, path coefficients, and $f^{2}$ (F. Hair Jr, Sarstedt, Hopkins, \& G. Kuppelwieser, 2014). $R^{2}$ is a value of the accurate prediction for the model. $R^{2}$ is expressed as a value that represents exogenous variables on endogenous variables (F. Hair Jr et al., 2014). Then, $Q^{2}$ is a facility to assess the predictive relevance of the inner model. Similarly, path coefficients are values that represent hypothesized related to the construct in this study. The path coefficient has a range value from -1 to +1 , va value close to +1 means a strong positive effect association while close to -1 means strong negative effect association (F. Hair Jr et al., 2014). Lastly, effect size (f2) was used to measure a construct's exogenous variables toward $\mathrm{R} 2$ in endogenous constructs (Hair Jr et al., 2017).

In short, Hair Jr et al. (2017) stated that $R^{2}$ is divided into three categories as $0.75,0.50$, and 0.25 . It shows that the prediction level is substantial, moderate, and weak. First, system quality, information quality, and e-service quality predict $46.6 \%\left(R^{2}=0.466\right)$ of customer satisfaction in the context of website quality. Thus, the accuracy of these variables on customer satisfaction is considered weak (Hair Jr et al., 2017). Furthermore, system quality, information quality, e-service quality, and customer satisfaction predict $57.7 \%\left(R^{2}=0.577\right)$ on repurchase intention in the context of website quality. Thus, the accuracy of these variables on repurchase intention is considered moderate (Hair et al., 2011).

Meanwhile, Hair Jr et al. (2017) suggest that predicting predictive relevance if the value of $Q^{2}$ must be more than 0 . This provides evidence that the detected value has good relevance. Therefore, this study has a value of 0.289 and 0.426 , respectively, on customer satisfaction and repurchase intention. As such, the model examined in this study has good relevance.

Lastly, effect size $\left(f^{2}\right)$ was used to measure a construct's exogenous variables toward $R^{2}$ in endogenous constructs. Specifically, Hair Jr et al. (2017) explained the effect size $f^{2}$ of each variable can be represented as small (0.02), moderate (0.15), and large (0.35). But, an effect value less than 0.02 indicates no effect. Table 5 shows system quality has a small effect on customer satisfaction and repurchase intention. Similarly, information quality also has a small 
effect on customer satisfaction and repurchase intention. The same goes for e-service quality that also has a small effect on customer satisfaction and repurchase intention. Last, customer satisfaction also has a small effect on repurchase intention.

Table 5 The effect size

\begin{tabular}{lcc}
\hline & Customer satisfaction & Repurchase Intention \\
\hline $\begin{array}{l}\text { Repurchase Intention } \\
\text { Customer satisfaction }\end{array}$ & & \\
e-Service Quality & 0,020 & 0,120 \\
Information Quality & 0,047 & 0,035 \\
System Quality & 0,121 & 0,037 \\
\hline
\end{tabular}

The structural model on path coefficients was tested using Bootstrapping 5000 sample to evaluate the construct indicators (Hair Jr et al., 2017) Critical t-Value for the two-tailed test: 1.65 (significance level =0.1), 1.96 (significance level $=0.05$ ), and 2.58 (significance level = 0.01) (Hair et al., 2011). Thus, Table 5 shows the direct, indirect, and total effect of each construct of exogenous variables on endogenous variables. First of all, the results of this study indicate that $\mathrm{H} 1 \mathrm{a}$ is accepted. System quality has a positive relationship with customer satisfaction $(\beta=0.385, p<0.01)$. System quality also has a positive and significant effect on repurchase intention $(\beta=0.224, p<0.01)$ thus $\mathrm{H} 2$ is accepted. Indirect effect system quality has positive and significant on repurchase intention $(\beta=0.119, p<0.01$ ). Direct effect from information quality on customer satisfaction $(\beta=0.236, p<0.01)$ and repurchase intention ( $\beta$ $=0.191, p<0.01$ ) has positive and significant. Thus, H3 and H4 are accepted. Indirect effect information quality has positive and significant on repurchase intention $(\beta=0.073, p<0.05)$.

Whereas, e-service quality has a positive and significant on customer satisfaction ( $\beta=$ $0.145, p<0.05)$, so $\mathrm{H} 5$ is accepted. Similarly, e-service quality towards repurchase intention is also positive and significant $(\beta=0.171, p<0.01)$. Also, the indirect effect of e-service quality has positive and significant on repurchase intention ( $\beta=0.045, p<0.01$ ) As such H6 is accepted. Last, customer satisfaction has a positive and significant on repurchase intention $(0,308, p<0.01)$, thus $\mathrm{H} 7$ is accepted. The result on the relationship between variables was illustrated in Figure 2.

Table 6 Direct, Indirect, and Total Effects of Relationships

\begin{tabular}{|c|c|c|c|c|c|c|}
\hline \multirow{2}{*}{ Path } & \multicolumn{2}{|c|}{ Direct effect } & \multicolumn{2}{|c|}{ Indirect effect } & \multicolumn{2}{|c|}{ Total effect } \\
\hline & $\beta$ & t-value & $\beta$ & t-value & $\beta$ & t-value \\
\hline Customer satisfaction-> Repurchase intention & 0,308 & $6,430 * *$ & & - & 0,308 & $6,429 * *$ \\
\hline e-Service Quality -> Customer satisfaction & 0,145 & $2,433^{*}$ & - & - & 0,145 & $2,434^{*}$ \\
\hline e-Service Quality -> Repurchase intention & 0,171 & $2,720 * *$ & 0,045 & $2,212 * *$ & 0,216 & $3,250 * *$ \\
\hline Information Quality -> Customer satisfaction & 0,236 & $3,673 * *$ & - & - & 0,236 & $3,673 * *$ \\
\hline Information Quality -> Repurchase intention & 0,191 & $2,937 * *$ & 0,073 & $3,320^{*}$ & 0,264 & $4,077 * *$ \\
\hline System Quality -> Customer satisfaction & 0,385 & $6,215^{* *}$ & - & - & 0,385 & $6,215^{* *}$ \\
\hline System Quality -> Repurchase intention & 0,224 & $3,292 * *$ & 0,119 & $4,520 * *$ & 0,343 & $4,996 * *$ \\
\hline \multicolumn{7}{|c|}{ Note: ${ }^{* *} p<0,01 ;{ }^{*} p<0,05$} \\
\hline
\end{tabular}




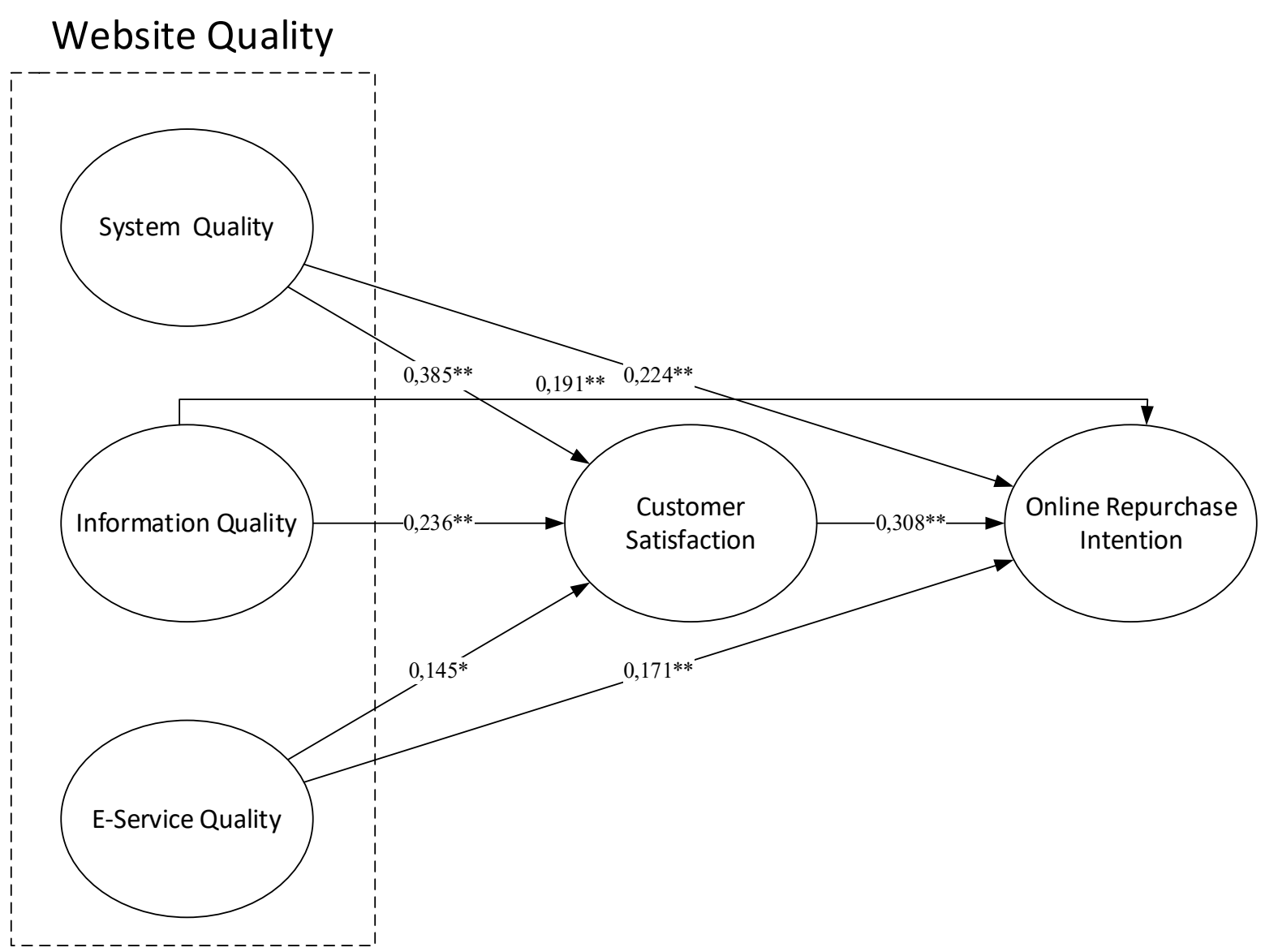

Figure 2 The Summary of the Relationship Between Variables

Note: $* * p<0,01 ; * p<0,05$

\section{DISCUSSION}

First, this study shows that system quality has a positive and significant effect on customer satisfaction. This implied that with a good system quality to customers such as tools (website tools) that are easy to use and searchable by consumers when needed. Then, the results of this study are consistent with Tam et al. (2019), which researches are in the same context e-commerce websites. However, the results found in this study are slightly different in how the company provides an excellent system to consumers. This is like giving security for consumer data when transacting online and providing a good appearance when consumers use the website to buy products, especially fashion products. Thus, consumers feel pleasure and it leads to customer satisfaction. To increase customer satisfaction, companies must ensure that their data is safe and must carry out the maintenance of the used system.

Second, this study found that system quality has a significant effect on online repurchase intention. This result implies that a good system can provide repeat purchases for fashion products on e-commerce websites. The results of this study are in accordance with A. Tandon et al. (2020) found that system quality has a significant effect on repurchase intention. However, this study explains that a good design can provide a sense of comfort, especially in making purchases and the transaction process for fashion products. In addition, by providing 
good navigation, the system can cause consumers to make repeated purchases, especially on the same website. Then, in increasing repurchase intention, the company must give a good display system such as letters colors that are easily recognized and read by consumers. In addition, it can be added with the addition of a good payment method system.

Third, the results of this study indicate that information quality has a significant influence on customer satisfaction. These findings imply that good information and consumer needs can provide customer satisfaction, especially in fashion products. This result is supported by a previous study by Jauhari, Kusumawati, and Nuralam (2019) that good information, especially in website quality, can provide customer satisfaction. The previous study was conducted on the Lazada e-commerce website in Malang, Indonesia. Thus, to improving the quality of information to customers, e-commerce must provide relevant information such as examples of fashion product categories and discounts and vouchers given to consumers.

Fourth, the results of this study found that information quality has a significant influence on online purchase intention. This result indicates that quality information can encourage consumers to make repeat purchases, especially on the same website. On the other hand, $\mathrm{H}$. Kim and Niehm (2009) stated that the quality of information on a website is an overall perception such as the level of accuracy and relevance of the information provided by the company. Thus, in improving this, the company must be able to provide good guidance and be easily understood by consumers, such as in processing transactions and bank/e-money and the flow of goods purchases. In essence, e-commerce must provide detailed products for packaged and shipped so that the information will provide safety and convenience for consumers to make repeat purchases.

Fifth, the results of this study indicate that e-service quality provides customer satisfaction on e-commerce websites in Indonesia. This continues to imply that good and optimal service quality can provide customer satisfaction. These results are consistent with the study by Galati et al. (2016) which carried out in the banking sector. However, this research is slightly different. The quality of service provided is a fast response or interaction when consumers ask questions about the stock of fashion products and variations of product models and sizes. So, in improving this, the company must improve the quality of chat and be responsive in answering questions from consumers. Therefore, the company can display the chat performance of each store on fashion products.

Sixth, the results of this study indicate that e-service quality has a positive and significant influence on online repurchase intention. This implies that quality service can influence the creation of repeat purchases on e-commerce websites. Therefore, good service quality is one of the factors to create online repurchase intention. The results of this study are the same as Suhaily and Soelasih (2017) who found that e-service quality influences repurchase intention in the online purchasing sector. But these results differ in that the services provided are essential and can be felt directly by consumers. Thus, to increasing e-commerce in Indonesia, the companies must continue to provide good and easy services such as a place for complaints from customers if the goods are not suitable and the response given must also be responsive.

Seventh, this study shows that customer satisfaction significantly influences the creation of online repurchase intention. This result implies that satisfaction is one of the main factors influencing consumers to make purchases again, especially on the same website. The results of this study are consistent with the previous research by Esposito Vinzi, Chin, Henseler, and 
Wang (2010) who found that customer satisfaction positively influences repurchase intention in the e-retailing sector. In research on the e-commerce website sector, companies can increase customer satisfaction through the latest information, such as providing feedback from consumers who previously gave photos or statements. This can increase consumer confidence when they will make repeated purchases. Then, they will also continue to provide convenience and an accurate purchasing process flow. Furthermore, they should provide the product according to the information listed on the e-commerce website. This can give a sense of making a repeated purchase.

\section{ACKNOWLEDGEMENTS}

The author would like to thank the Bandung State Polytechnic, Department of Business Administration, and those who have assisted in this research.

\section{REFERENCES}

Ajay Kaushik, N., \& Potti Srinivasa, R. (2017). Effect of website quality on customer satisfaction and purchase intention in online travel ticket booking websites. Management, $7(5)$, 168-173.

Camilleri, M. A. (2021). E-commerce websites, consumer order fulfillment and after-sales service satisfaction: the customer is always right, even after the shopping cart checkout. Journal of Strategy Management.

Chinomona, R., Masinge, G., \& Sandada, M. (2014). The influence of e-service quality on customer perceived value, customer satisfaction and loyalty in South Africa. Mediterranean Journal of Social Sciences, 5(9), 331.

DeLone, W. H., \& McLean, E. R. (2004). Measuring e-commerce success: Applying the DeLone \& McLean information systems success model. International Journal of electronic commerce, 9(1), 31-47.

Esposito Vinzi, V., Chin, W. W., Henseler, J., \& Wang, H. (2010). Handbook of partial least squares: Concepts, methods and applications: Heidelberg, Dordrecht, London, New York: Springer.

F. Hair Jr, J., Sarstedt, M., Hopkins, L., \& G. Kuppelwieser, V. (2014). Partial least squares structural equation modeling (PLS-SEM) An emerging tool in business research. European Business Review, 26(2), 106-121.

Filieri, R., McLeay, F., \& Tsui, B. (2017). Antecedents of travellers' satisfaction and purchase intention from social commerce websites. In Information and Communication Technologies in Tourism 2017 (pp. 517-528): Springer.

Ford, E. W., Huerta, T. R., Diana, M. L., Kazley, A. S., \& Menachemi, N. (2013). Patient satisfaction scores and their relationship to hospital website quality measures. Health marketing quarterly, 30(4), 334-348.

Galati, A., Crescimanno, M., Tinervia, S., \& Siggia, D. J. I. J. o. W. B. R. (2016). Website quality and internal business factors. 
Hair, J. F., Ringle, C. M., \& Sarstedt, M. (2011). PLS-SEM: Indeed a silver bullet. Journal of Marketing theory and Practice, 19(2), 139-152.

Hair, J. F., Sarstedt, M., Ringle, C. M., \& Mena, J. A. (2012). An assessment of the use of partial least squares structural equation modeling in marketing research. Journal of the academy of marketing science, 40(3), 414-433.

Hair Jr, J. F., Sarstedt, M., Ringle, C. M., \& Gudergan, S. P. (2017). Advanced issues in partial least squares structural equation modeling: Sage Publications.

Hsu, C.-L., Chang, K.-C., \& Chen, M.-C. (2012). The impact of website quality on customer satisfaction and purchase intention: perceived playfulness and perceived flow as mediators. Information Systems e-Business Management, 10(4), 549-570.

Jauhari, M. T., Kusumawati, A., \& Nuralam, I. P. (2019). The impact of website quality on consumer satisfaction and purchase intention (study case of e-commerce Lazada Indonesia in Malang city). Jurnal Administrasi Bisnis, 67(1), 54-61.

Jeon, M. M., \& Jeong, M. (2017). Customers' perceived website service quality and its effects on e-loyalty. International Journal of Contemporary Hospitality Management.

Katadata. (2020a). Riset KIC-Kredivo: Produk Busana Paling Laris di E-Commerce. Retrieved from https://katadata.co.id/desysetyowati/digital/5f297aa120d79/riset-kic-kredivoproduk-busana-paling-laris-di-e-commerce

KataData. (2020b). Shopee, E-Commerce dengan Pengunjung Situs Tertinggi Kuartal III 2020.

Kim, G., Shin, B., \& Kwon, O. (2012). Investigating the value of sociomaterialism in conceptualizing IT capability of a firm. Journal of Management Information Systems, 29(3), 327-362.

Kim, H., \& Niehm, L. S. (2009). The impact of website quality on information quality, value, and loyalty intentions in apparel retailing. Journal of interactive marketing, 23(3), 221233.

Kuo, Y.-F., Wu, C.-M., \& Deng, W.-J. (2009). The relationships among service quality, perceived value, customer satisfaction, and post-purchase intention in mobile value-added services. Computers in human behavior, 25(4), 887-896.

Lin, H.-F. (2007). The impact of website quality dimensions on customer satisfaction in the B2C e-commerce context. Total Quality Management Business Excellence18(4), 363378.

Malhotra, N. K., Birks, D. F., \& Nunan, D. (2017). Marketing Research PDF eBook 5th edition: Pearson Higher Ed.

Oni, A. A., Adewoye, O. J., \& Eweoya, I. O. (2016). E-banking users' behaviour: e-service quality, attitude, and customer satisfaction. International Journal of Bank Marketing.

Parasuraman, A., Zeithaml, V. A., \& Malhotra, A. (2005). ES-QUAL: A multiple-item scale for assessing electronic service quality. Journal of Service Research, 7(3), 213-233.

Phuong, N. N. D., \& Dai Trang, T. T. (2018). Repurchase intention: The effect of service quality, system quality, information quality, and customer satisfaction as mediating role: a PLS approach of $\mathrm{m}$-commerce ride hailing service in Vietnam. Marketing Branding Research5(2), 78.

Prastiwi, S. K., \& Iswari, P. W. (2019). The Roles of Trust within Information Quality and Price to Engage Impulsive Buying Behaviour to Generate Customer's Repurchase Intention: A Case of M-Commerce in Indonesia (GoFood). KnE Social Sciences, 446-462-446-462. 
Qalati, S. A., Vela, E. G., Li, W., Dakhan, S. A., Hong Thuy, T. T., \& Merani, S. H. (2021). Effects of perceived service quality, website quality, and reputation on purchase intention: The mediating and moderating roles of trust and perceived risk in online shopping. Cogent Business Management, 8(1), 1869363.

Rohwiyati, R., \& Praptiestrini, P. (2019). The Effect of Shopee e-Service Quality and Price Perception on Repurchase Intention: Customer Satisfaction as Mediation Variable. Indonesian Journal of Contemporary Management Research, 1(1), 47-54.

Sharma, G., \& Lijuan, W. (2015). The effects of online service quality of e-commerce Websites on user satisfaction. The Electronic Library.

Shin, J. I., Chung, K. H., Oh, J. S., \& Lee, C. W. (2013). The effect of site quality on repurchase intention in Internet shopping through mediating variables: The case of university students in South Korea. International Journal of Information Management, 33(3), 453-463.

Singh, T., Malik, S., \& Sarkar, D. (2016). E-commerce website quality assessment based on usability. Paper presented at the 2016 International Conference on Computing, Communication and Automation (ICCCA).

Statista. (2019). Pendapatan E-Commerce Indonesia versi Statista 2017-2023. Retrieved from https://www.statista.com/study/60342/e-commerce-in-indonesia/

Suhaily, L., \& Soelasih, Y. (2017). What effects repurchase intention of online shopping. International Business Research, 10(12), 113-122.

Suhartanto, D. (2014). Metode Riset Pemasaran. Bandung: Alfabeta.

Sun, J., Yang, Z., Wang, Y., \& Zhang, Y. (2015). Rethinking e-commerce service quality: does website quality still suffice? Journal of Computer Information Systems, 55(4), 62-72.

Tam, C., Loureiro, A., \& Oliveira, T. (2019). The individual performance outcome behind ecommerce. Internet Research.

Tandon, A., Aakash, A., \& Aggarwal, A. G. (2020). Impact of EWOM, website quality, and product satisfaction on customer satisfaction and repurchase intention: moderating role of shipping and handling. International Journal of System Assurance Engineering Management1-8.

Tandon, U., Kiran, R., \& Sah, A. N. (2017). Customer satisfaction as mediator between website service quality and repurchase intention: An emerging economy case. Service Science, 9(2), 106-120.

Tenenhaus, M., Vinzi, V. E., Chatelin, Y.-M., \& Lauro, C. (2005). PLS path modeling. Computational statistics \& data analysis, 48(1), 159-205.

Tresna, P. W., Suryanto, \& Haidysirly, H. (2019). Effect of perceived value on repurchase intention in e-commerce: a study on the Female Daily mobile application. International Journal of Trade Global Markets12(3-4), 373-380.

Tsao, W.-C., Hsieh, M.-T., \& Lin, T. M. (2016). Intensifying online loyalty! The power of website quality and the perceived value of consumer/seller relationship. Industrial Management Data Systems.

Wilson, N., \& Christella, R. (2019). AN EMPIRICAL RESEARCH OF FACTORS AFFECTING CUSTOMER SATISFACTION: A CASE OF THE INDONESIAN E-COMMERCE INDUSTRY. DeReMa (Development Research of Management): Jurnal Manajemen, 14(1), 21-44. 
77 | Journal of Marketing Innovation, Volume 1 Issue 1, Sept 2021 Hal 62-77

Zehir, C., \& Narcıkara, E. (2016). E-service quality and e-recovery service quality: Effects on value perceptions and loyalty intentions. Procedia-Social Behavioral Sciences229, 427443.

Zhang, K. Z., Xu, H., Zhao, S., \& Yu, Y. (2018). Online reviews and impulse buying behavior: the role of browsing and impulsiveness. Internet Research. 